\title{
Psychology behind Clandestine Affairs in an Interpersonal Romantic Liaison
}

\author{
Disha Khanna \\ GNA University, Phagwara, India \\ Email: disha.khanna@gna.university, dishakhanna08@gmail.com
}

Received 19 August 2015; accepted 4 September 2015; published 11 September 2015

Copyright (C) 2015 by author and OALib.

This work is licensed under the Creative Commons Attribution International License (CC BY). http://creativecommons.org/licenses/by/4.0/

(c) (i) Open Access

\begin{abstract}
Clandestine love affairs and meetings between love smitten couples are common issues since time immemorial. Love is one of the most profound emotions known to human beings. Lovers in societies who are conservative need to have clandestine meetings, that is, they can meet only secretly even for their simple romantic relationships. There is nothing novel among these rendezvous' between two loving parties. But the matter of concern that stands supreme is the psychology or in other words the working of the mind of these couples that ignites their souls to enter into an intimate relationship. In the current scenario, clandestine affairs and romantic liaisons are very common among people of any age group. The couple under the spell of romantic union is least bothered to share his experience with the family members or even friends; they keep it to themselves and live in their own euphoric world. The current research effort will penetrate deep in highlighting the strong psychology behind these interpersonal romantic affairs. The psychological impact behind the romantic initiation leading into the saga of an interpersonal romantic relationship is a matter of strong discussion. The paper will aid in highlighting how the two unknown bodies meet and interact with each other, actually ignite or extinguish aspirations for the impending future. The psychology behind this clandestine affair, sans awareness to the third party is centripetal on the couple's flight of imagination in the deep recesses of their heart and their virtual behavior towards each other.
\end{abstract}

\section{Keywords}

Clandestine Affairs, Digital Age, Interpersonal Relationship, Love Smitten Couples, Romantic Liaisons, Tete-e-Tete

Subject Areas: Psychology

\section{Introduction}

Anything kept secret or hidden from the external world is clandestine. The covert relationship possessed by a

How to cite this paper: Khanna, D. (2015) Psychology behind Clandestine Affairs in an Interpersonal Romantic Liaison. Open Access Library Journal, 2: e1870. http://dx.doi.org/10.4236/oalib.1101870 
male and a female is labeled as clandestine affair or relationship. The lovers who have conservative bent of mind, impromptu need to plunge into clandestine meetings, that is, they can meet only secretly for their simple romantic liaison. This trend of secretive meeting is not new. Lovers have been engaged in this practice since time immemorial. But in the current digital age, occurrences of these romantic affairs are more recurrent and rather easy to pursue. With the outstanding advent and consistent usage of social networking sites, Internet chat rooms, and online dating sites among the youngsters have led to the widespread happenings of love duos. It is witnessed that these love engrossed couples at their tender age don't even give a second thought to what they are into. They are extremely weak in their practical thinking capacity and thus their love psychology is just passionate to have a secretive and simple love affair. Thus, they are least concerned with their working and the psychology behind their obscure actions. Their thinking capacity is been engulfed and overpowered by the strong influence of their unlawful actions. At times, the love affairs among the couple pop up via an online tool, where they have been into interpersonal communication without even having a face to face meeting with them. But the attraction is so intense that it leads them to take strong and significant decisions of their life in the form of wedlock. The current research paper will endeavor to provide the psychology behind these interpersonal clandestine romantic liaisons.

\section{Factors Affecting Romantic Liaisons between Couples}

There are numerous factors that can influence the rendezvous between couples. These relationships if turned strong further lead to nuptial ties between the couples. According to Lykken \& Tellegen [1], individuals' selection of one mate over happens largely by chance. Moreover, it is an age old saying that marriages are made in heaven. Still individuals are really fussy in matters pertaining to mate selection. In the words of Buss [2], selection of a suitable mate for oneself incorporates a series of strategies engaged by individuals who are attempting to widen their horizon of reproductive value.

\section{Psychology behind Clandestine Affairs}

The people in a love circle have their own psychology and working style; little bothered about the repercussions it is going to lead in the times to come on themselves as well as on the family. Segel is of the conviction, "People are more likely to start romantic relationships with individuals who are physically proximate than they are with those at a distance" [3]. People tend to interact with others who are alike to themselves in terms of variables such as age, socio economic status, and education. The first step in the process of falling in love is the initial attraction. It's the powerful moment when we meet another person and feel energized and are immediately aware of our heart pounding.

As a consequence, the group from which individuals are likely to pick a romantic partner is reasonably homogeneous. Here the working of the individual's psychology is of paramount significance. "Falling in love is associated with increased energy, narrowing of mental focus, sometimes sweaty palms, light-headedness, racing heart, and a lot of positive feelings," says Needle [4], an associate professor and coordinator of Clinical Experiences at South University, West Palm Beach.

The choices people make concerning relationship initiation may be influenced by their perceptions of the other person's social competence to how lonesome they feel when they first encounter a prospective partner. When people first convene, they exchange information that is moderately impersonal and limit the number of diverse topics they converse. As they come to know and trust each other, partners share a larger number of topics and unveil more intimate information to each other about those topics leading to greater emotional attachment in their relationships as well as greater relational contentment.

Altman and Taylor argued, "If partners perceive that their interactions are more pleasing than not, they are likely to continue their association with each other. In addition to assessing how rewarding their interactions are, individuals consider what other alternative relationships might be available to them as well as how those alternatives compare with their current relationship" [5].

By and large, when potential partners primarily come across each other, they discuss fairly innocent and general issues like the weather, where they are from, what they do for a living. Normally, they do not talk about vastly emotional personal matters such as their apprehensions, worries, or fantasies. As the amount of verbal communication between partners' increases, their hesitation and insecurity tends to decrease. It is only after people are acquainted to each other that they embark on exchanging more personal information because their uncertainty has faded. 


\section{Strategies to Initiate Strong Relationships}

It is generally witnessed that it is the physical attraction towards the opposite sex that is one of the prime reasons for any love relationship. Even before a couple starts entering into the world of verbal communication, it is originally the physical energies that feel connected to each other. Slowly the train moves on to another angle of fondness and similarities that makes the liaison and the bond all the more solid.

An individual who has strong attraction towards the person of the opposite sex may intentionally employ certain tactics to be in proximity with her. Naturally, here he is going to utilize his psychology to implement his smart skills in the form of verbal interpersonal communication to enhance and reinforce his relationship with the individual. People's perceptions of their partner's physical charisma have been associated with relational qualities such as commitment, fervor, familiarity, contentment, and marital adjustment. Bell and Daly (1984) [6] has highlighted certain strategies to dynamically set off relationships-

1) Focusing on commonalities (like-minded people flock together. e.g., highlighting similarities, demonstrating equality),

2) Showing self-involvement and concern (e.g., finding ways of regularly "running into" the other),

3) Involving and engaging the other (e.g., participating in activities the other person enjoys, including the other in activities),

4) Demonstrating care and concern (e.g., listening, being altruistic),

5) Displaying politeness (e.g., letting the other have control over plans, acting interested),

6) Encouraging mutual trust (e.g., being honest, being reliable), and

7) Demonstrating control and visibility (e.g., being dynamic, looking good).

\section{Proximity in Love Relationships on Grounds of Similarity}

The magnitude and worth of similarity in two individuals of opposite sex are of great eminence in deciding the impact of a love relationship. There is a strong inclination in people that have a tendency to prefer spouses who are relatively akin to them in terms of race, religion, ethnicity, education, and age. Partners who have similar preferences with regard to role performance and leisure activities are more compatible and easily enter into a duo.

\section{Time Engagement between Couples}

The time duration a couple spends together plays a solid role in intensification of the roots of any intimate relationship. The amount of time couples spend engaged in various activities together on a day-to-day basis leads to stronger intimacy between them. Moreover, partners who have been together for long periods of time have more stable relationships than those who have been together for short periods or those who have ruined their relationship.

\section{Female and Male Psychology behind a Romantic Relationship}

Females are hypersensitive and more prone to apply their psychology in matters pertaining opposite sex and their choice of intimate love relationship. They possess stronger preferences than do men for partners who have good earning potential or other valued resources for seeking mates who will be excellent donors for their children. On the other hand, males have a peculiar and purely different perspective. They have instinctively stronger preferences for physically attractive mates than do women for the sole hunt of mates who are productive and able to bring into being healthy off springs. Any romantic liaison solely depends on the mental stance of the couple. The way they think and act actually affects a clandestine meet. The individual gender psychology makes it highly apparent as to what they are up to and what exactly they demand from a clandestine affair.

\section{Reasons for Uncertainty in Close Relationships}

The people in the preliminary stage of a love relationship undeniably experience uncertainty about their partner's opinions, morals, and feelings. But as the days and time span of the love ties between the couple increases, steadily the intensity of the trustworthiness and bond gets strengthened.

Confidence plays a key role in establishing any cherished interpersonal relationship. Be it a relationship between a connubial relationship and a love duo between newly entered relationships, buoyancy needs to be utterly 
strong between two love stricken individuals.

Secondly, if people perceive that they are powerless to predict or explain their own relationship-relevant attitudes or behaviors, it leads to self-uncertainty. This self-uncertainty becomes a root cause to any ineffective close relationship.

Thirdly, at times a condition comes which reflects individuals' perceived incapacity to envisage the other person's attitudes or behaviors leading to partner improbability. This level of doubtfulness is a very familiar occurrence between couples. It is liable to impinge on any gender because of their behavioral actions towards each other. Basically, it is the exchange of thoughts and ideas between the people at the initial level that leads to dwindling relationships.

\section{Discussion}

Even in the current scenario, the males and females are still attracted towards each other leading into secretive meetings between the couple. But with the advent of the digital age, a strong revolution in the love relationships between couples has been witnessed. Computers, cell phones, and the Internet are integral to many people's lives and, as a consequence, touch their relationships making them closer and easily accessible and approachable. Gone are the days when people used to fall in love at first sight and follow that true love till their life. In the words of Marston \& Hecht [7], love these days has acquired multifarious paths followed by people. The social networking sites and what's app have completely altered and triggered the way a couple thinks and enlarges their love duo. Individuals have a unique and unusual mind set in matters concerning intimate relationships. They have their own psychology of enhancing their clandestine affairs. Though earlier also the guardians were never aware about the pool their children have plunged into. In the present era also the things have unchanged, but it is only the psychology behind the selection and the channel of clandestine interpersonal relationships that has attained a novel visage. Things previously were all the same, couples earlier also used to meet but it is only their style and communication which have gained the reversal.

\section{Conclusion}

The psychology behind the clandestine interpersonal relationship is an essential attribute of any passionate and idealistic relationship. According to Parks (2006) [8], interpersonal communication is a dire requisite between the besotted couples to instigate a close romantic affiliation. The way they come within the reach of prospective partners, the nature of questions they pose, and the information they reveal all influence whether and how their relationships develop.

\section{References}

[1] Lykken, D.T. (2002) How Relationships Begin and End. In: Vangelisti, A.L., Reis, H.T. and Fitzpatrick, M.A., Eds., Stability and Change in Relationships, Cambridge University Press, New York, 83-102. http://dx.doi.org/10.1017/CBO9780511499876.006

[2] Buss, D.M. (1994) The Evolution of Desire: Strategies of Human Mating. Basic Books, New York, 43-45.

[3] Segal, M.W. (1974) Alphabet and Attraction: An Unobtrusive Measure of the Effect of Propinquity in a Field Setting. Journal of Personality and Social Psychology, 30, 654-657. http://dx.doi.org/10.1037/h0037446

[4] Needle, R. (2006) Clinical Experiences. West Palm Beach, 36.

[5] Altman, I. and Taylor, D.A. (1973) Social Penetration: The Development of Interpersonal Relationships. Holt, Rinehart, \& Winston, New York, 459.

[6] Bell, R.A. and Daly, J.A. (1984) The Affinity-Seeking Function of Communication. Communication Monographs, 51 91-115. http://dx.doi.org/10.1080/03637758409390188

[7] Marston, P.J., Hecht, M.L. and Robers, T. (1987) "True Love Ways”: The Subjective Experience and Communication or Romantic Love. Journal of Social and Personal Relationships, 4, 387-407. http://dx.doi.org/10.1177/0265407587044001

[8] Parks, M.R. (2006) Personal Relationships and Personal Networks. Lawrence Erlbaum, Mahwah, 93. 